\title{
JIEP 関西支部発足に至るまでのときを顧みて
}

\author{
貫井 孝*
}

Establishment of the Kansai Branch of JIEP: A Short Retrospective

\author{
Takashi NUKII*
}

*京都大学大学院横断教育プログラム推進センターデザイン学リーディング大学院（ 7 600-8815 京都市下京区中堂寺粟田町 $91 \quad$ KRP9 号館 506）
* Leading Graduate School of Design, Center for Educational Program Promotion in Graduate School, Kyoto University (\#506, KRP Bld.9, 91 Chudoji, Awata-cho, Shimogyo,
Kyoto 600-8815)

本年,「エレクトロニクス実装学会」創立 20 周年を迎え るにあたり, 創立前, そして今日に至るまでご尽力賜った 多くの方々に心より感謝するとともにさらなる発展を祈念 する次第です。

本稿では，関西の実装業界に身を置かせていただいた一 人（当時, シャープ）として, 1990 年代半ばから約 10 年 間ほどの時期にフォーカスし, 関西支部設立に至るプロセ スを振り返るとともに，実装技術の変遷やこれからについ ても若干触れてみたい。

さて, 言うまでもなく 1980 年から 2000 年代にかけて は, 日本のエレクトロニクス産業が大きく進展した時期で ある。この要因として, エレクトロニクス製造業の一つの 産業基盤, あるいはプラットフォームとして「実装」が間 違いなく進化しながら機能していたように思われる。つま り，これが存在したからこそエレクトロニクス製品は成就 し，世の中に旅立ち，人々の生活や社会を豊かにする一つ の原動力になったのである。その結果, 当該産業に関わる
ビジネスが隆盛を誇るに至ったことは言うまでもない。 1980 年代は,「SMT (Surface Mount Technology)」が，材 料・プロセス・設備など生産システムとして進化を遂げ, これが製品製造の基幹を担うようになる。1990 年前後に登 場し話題をさらったハンディカムコーダもその結実の一つ であろう。そして，もう一例を挙げてみよう。1990年代の 後半，あっという間に普及した携帯電話であるが，この ハードとしてのベースになったのは, 中小型液晶モジュー ルを実現したドライバー IC 実装，そして CSP (Chip Size Package) とその実装，さらにこれらが搭載されるビルドアッ プ基板などが主たる要素である。これらの実装要素技術・ 材料・装置がハーモナイズされた生産システムとして確立 し，そして各分野の実装技術者の融合があってはじめて携 帯端末のビジネス，産業が成り立ったと言っても過言では ないと思っている。そして，その流れは，現在のスマート フォンにたどり着くのである。眓 1 には時代ごとの実装関 連技術の代表例を，民生分野を中心に（筆者の独断で）記

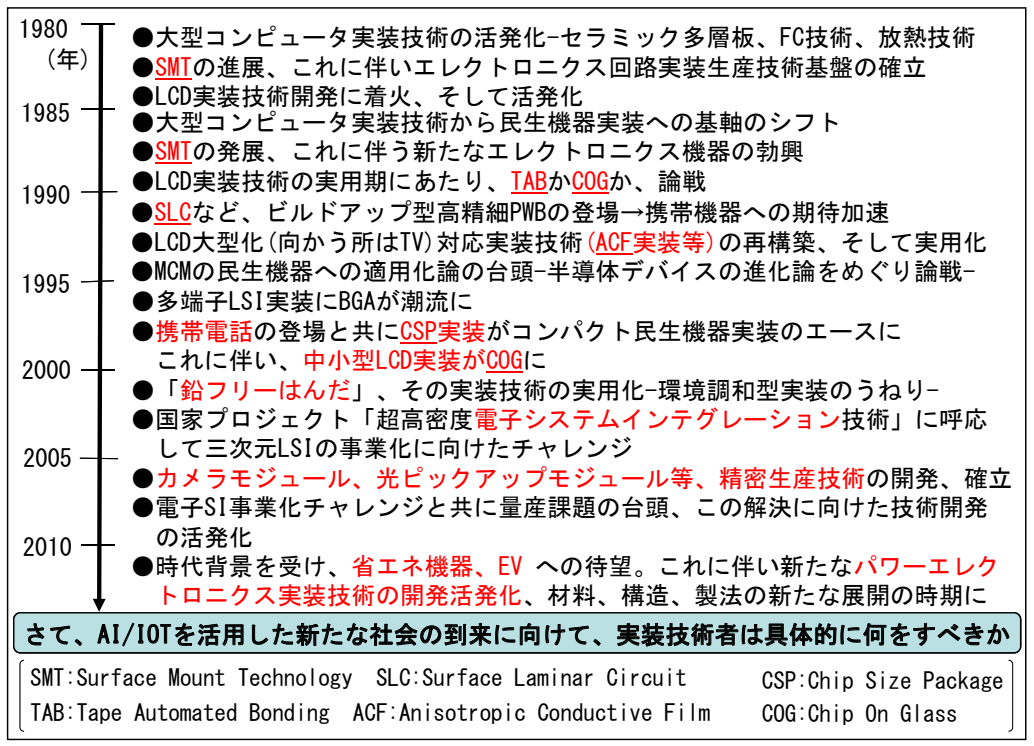

図 1. エレクトロニクス実装関連技術の推移（一例） 
してみた。参考になれば幸いである。

ところで, こんな状況の中で, 業界活動も学会活動も必 然的に年々盛んになって行くことになる。ワクワク感が取 りまく時代背景もあり, 多くの方々との会話, 議論は掛け 替えのない場でもあった。しかし, いつも関西から東京に 出かけて夜遅くに戻ってくるという私たち関西実装関係者 の環境は, それなりの厳しさを伴っていたことも否定でき ず,「何とか少し改善できる方法はないかなあ, 関西の地で 懸命に励む若い人のエネルギを結集できる場はでけへんや ろか, いや絶対必要やなあ, ならばそんな場を今後のため にもどうしても作らなあかんなあ, そなやってみようか」と 当時, 松下電器 - 畑田さん, 東レ・井上さん, 日本 IBM · 西田さん等々と会うたびに語りあっていた。

だが冷静に考えると, 何の形も実績もない関西に簡単に 拠点 (支部) 如きをつくるというハードルは誰が考えても 高く, まずはコツコツと実績を積んで行こうということで 意思統一した。そして, 試行錯誤の結果, ようやく 1996 年 11 月 8 日, 関西ワークショップを「コープイン京都」で開 催することに辿り着いたのである。比較的安価でアクセス もまずまずということで場所は決めたものの誰も知らない 関西のイベント。不安だらけだったが，とにかく始めた以 上は絶対やり抜こうとテーマの抽出・交渉, 参加者募集な ど，懸命にFAX 送信を駆使したことを覚えている。そんな 中, 前述の各位に加え若い諸君の大きな力添えは, 「きっと やれるだろう」との勇気に変わっていった。その甲斐あっ てか想定以上の参加者であったことは記憶にあるが, 残念 ながら私のもとに詳細な記録は残っていない。最初の数回 は意識的にパネルデイスカッションのパネラーや招待講演, 発表を関東の諸氏にお願いし, 関西ローカルにならないよ うに努めた（積極的に協力いただいた当時 NTT アドバンス テクノロジー・大崎さん, $\mathrm{NEC} \cdot$ 盆子原さん, 嶋田さん, 東芝・福岡さん, 皆々様, ありがとう)。回を重ねていくう ちにアフターは「四条 $\rightarrow$ 祇園」に定型化されていくが, 今 回，その件は省略と致したく。その後，関西ワークショッ プは, 運営形態を変えながら内容をより充実させ, 今日に 至るまで続くのである。

当初 2-3 回の関西ワークショップを経ると, 何とか関西 のイベントが一つ成立したかなあという実感は関係した各 位に徐々に生まれつつあった。しかし，これだけでは不十 分, 何とか次は「毎年, 関西開催のシンポジウム（実装学 会)」を開催できないものか, と前記諸氏はもとよりワーク ショップの実行委員からも待望論が芽生えて来たのが 1997 年から 1998 年あたりである。

一方, このころは, 実装関連学会にとっても大きな変化 点を迎える。1997年に「エレクトロニクス実装協会」と 「プリント回路学会」の合併準備委員会が設置され, 1998 年には, 新たに「エレクトロニクス実装学会」の発足へと 展開する。合併に伴い, それぞれのイベントの見直し, 位
置づけも当然ながら議論されることになる。その議論の 1 つにMES も含まれていた（なお，1998 年にはエレクトロ ニクス実装学会として, MES98 が当時, 東芝・岩瀬組織委 員長のもとで大宮ソニックシティにて開催されている。）。

そんな中, 畑田さんはじめ前述の関西諸氏に,「ここは一 つ腹を括って関西でやる提言をしてみようか」と相談,「や るしかない, 今やで」の意を受け，いよいよ上京。関西か らいわば，議論の横入をした形で「MES 関西開催」を関東 の関係諸氏にその効果や実現性を説いて回った。当時学会 理事でNTTアドバンステクノロジーの大崎さん, 同じく学 会理事・東芝の岩瀬さん, 事務局の平田さん達には迷惑な 関西人に対して辛抱を重ねて話を丁寧に聞いて頂いたこと を鮮明に覚えている。そして，結果的には，多くの皆様方 のご支援を賜り，その願いは叶えられ，MES99 を関西で開 催することが正式に承認されるに至った。

関西で初のシンポジウム MES99 は, 1999 年 10 月 29-30 日, 大阪大学 コンベンションセンターにて開催されること になった。この開催には, 大阪大学・産研・菅沼先生にた いへんご尽力を頂き (その後も2006 年まで阪大開催), 関 西開催の礎をつくることになった。心より感謝したい。

この関西での初回（第 9 回 MES）は, コケた時の責任取 り役を私が務めただけで，実質的には畑田さん，菅沼先 生, 西田さん, 当時 NEC ・ 嶋田さん達の精力的な活動に支 えられた。また，面倒な関西人にも真摰に対応頂いた大崎 さんや岩瀬さんにも顧問に就いて頂き, 成功に向けて最後 までご支援を賜つた。

そのような甲斐あって, 参加者は 420 名, また論文発表 も 84 件とまずまずのスタートをきり，ホッとしたことを覚 えている（その後, 2002 年には参加者 621 名, また論文発 表 112 件と，より活発化していった記録が残されている。）。 やや蛇足ではあるが，このMES99 の参加募集として， 下記のような案内文を掲載している。今となっては, いさ さか前のめりの感は拭えないが, 当時の温度を多少なりと も感じて頂ければ幸いである（なお，国家プロジェクト， $\mathrm{ASET}^{\dagger}$ 「超高密度電子システムインテグレーション技術」 もこの年からスタートし，3 次元実装への取り組みが国レ ベルで始まった時である。)。

「21 世紀，新実装時代へのプロローグ一電子システム集 積化技術の構築に向けて一」

21 世紀を目前にした今，時の流れはドラスティック な状況の変化をもたらし, (1) 通信・放送における変革 (デジタル化, 融合など), (2) 半導体技術における変革 (超高集積化，高速化など)，(3)これらに伴うネット ワーク・モバイル商品群の登場, (4) 環境・安全問題の 急浮上（鉛フリー, EMI など), (5) 生産のグローバル 展開など, われわれを取り巻く環境は,「実装」にも大 きな課題を提示しています。

これらの変化に対応していくためには, 従来の枠組 
みを超え，材料・システム構成・生産技術・設計など 幅広い総合的見地からの「実装技術」への取り組みが 不可欠になってきています。この時代背景を踏まえ，

メインテーマを「21 世紀, 新実装時代へのプロローグ

一電子システム集積化技術の構築に向けて一」と題

し, 第 9 回を迎えるMES99（マイクロエレクトロニク

スシンポジウム）を初めて関西の地で開催する運びと

なりました。幅広い分野から多くの方々の参画, 交流 を期待いたします。

そして, 2000 年に入り, 関西では, この MES, 関西ワー クショップの $2 つ の$ 柱を中心に, より一層充実した内容を 求め進化していくこととなる。それと共に, 若手の実装技 術者の活発な活動にも支えられ，やがて，2003 年 12 月の 「関西支部」設立へと慗がって行くのである。なお，私自身 は, 2000 年 4 月からいわゆる実装から離れ, 白物家電の開 発・事業化, 電子デバイスの開発・事業化の道を歩むこと になり，支部設立そのものにはほとんど抒役に立てず，今 な扮申し訳なく思っている。しかし, 多くの先輩・後輩た ちに,「関西支部」設立を経て今日に至るまで導いて頂いた こと，感謝の気持ちで一杯である。

以上，主として関西支部設立に至る歴史の一部を振り 返ってみたが*1, ここに記した時代からもう 20-30 年の時 が経過している。しかし, この間, 私が当学会のイベント や学会での活動を通じて多くの方々との出会い, 交流の中 で学ばせて頂いたことは途輬もなく大きい。その昔,「学会 は人を育てる場でもある」とある先輩から言われたことが あるが, それを今, 実感し, 心から感謝している。 JIEP，並びに関西支部が，これからもさらに広い業種，

※1 危うい記憶を辿りながらの回想ゆえに, 若干事実との誤差があるかもしれ ないこと, ご容赦頂ければ幸いである。
異分野の方々が集い, 交わり会う場, 学び合う場になり, その中から小さくもキラッと光るイノベーションの芽が生 まれ，やがて世界をリードするビジネスに育ち，イノベー テイブ人材が飛び立つことを祈ってやまない。

(2018.7.9- 受理)

\section{†用語解説}

MES : Microelectronics Symposium の略称からスタートし たシンポジウムであるが，むしろ「MES」，ないしは 「マイクロエレクトロニクスシンポジウム」と称される のが一般的である。JIEP の主催する主要行事の 1 つ で，日本語での発表・論文集をべースとするシンポジ ウム。1985 年第 1 回が早稲田大学で開催され，1998 年 第 8 回まで関東圈で実施された。1999 年第 9 回目に初 めて関西 (大阪大学) で開催されて以降, 関西・東海 地区を中心に実施されている。

ASET :「技術研究組合超先端電子技術開発機構」の英表 記(Association of Super-Advanced Electronics Technologies) の略称。「産学官の連携によって日本の半導体や電子デ バイスをはじめとする先進技術開発を推進し，技術力 を強化する」という目的で 1996 年に設立された団体で ある。2013 年, 解散に至る。

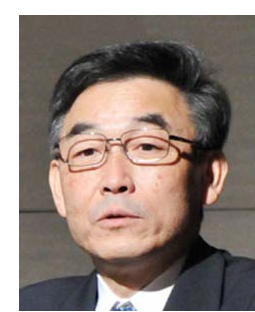

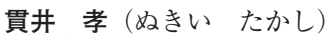

著者紹介

1973 年京都大学工学部卒業, シャープ (株) 入 社。中央研究所を皮切りに, エレクトロニクス実 装技術の研究開発, 事業化に従事。同社電化シス テム事業, 電子デバイス事業を経て常務執行役員 生産技術統轄を最後に退任。2012 年より大阪大 学・産業科学研究所・招聘教授, 京都リサーチ パーク (株)・フェロー。現在, 京都大学デザイン 学リーデイング大学院特任教授。工博 (大阪大学)。 